\title{
Ureteric Fistula
}

National Cancer Institute

\section{Source}

National Cancer Institute. Ureteric Fistula. NCI Thesaurus. Code C78663.

An abnormal communication between the ureter and another organ or anatomic site. 